\title{
DEVELOPMENT OF PEDAGOGICAL MASTERY OF FUTURE VOCATIONAL TRAINING TEACHERS UNDER CONDITIONS OF EDUCATIONAL TRANSFORMATIONS
}

\author{
Vasyl Kovalchuk ${ }^{1}$ \\ Inna Marynchenko ${ }^{2}$ \\ Liliia Hrytsenko ${ }^{3}$
}

DOI: https://doi.org/10.30525/978-9934-588-15-0-10

Abstract. The problem of pedagogical skills of the future teacher of professional training formation is analysed in the work presented. The necessity as for the development of the quality is primarily due to the needs of the labour market for new education pedagogues possessing and revealing critical thinking, communication skills, digital competence, etc. The authors summarize in the idea concerning the following fact that the teacher-master is a highly-developed personality, a specialist of high culture, a master of one's work, who posessing perfect psychological knowledge, awareness in various fields of science and art, mastery in the subject he teaches, training and upbringing skills. The objective of the article is to reveal some peculiarities concerning the ways of development of future teachers of vocational training pedagogical skills in the educational process of Oleksandr Dovzhenko Hlukhiv National Pedagogical University. The authors believe that the quality can be improved when the appropriate environment is created. The development of the specified quality is carried out by means of involving teachers and students in the activities provided by scientific laboratory «Innovative training technologies», performing researches and studies within the initiatiated research theme of the work of the department «Pedagogical mastery of the teacher of vocational training development under conditions of educational transformations» and training

\footnotetext{
${ }^{1}$ Dr.hab. in Pedagogics, Professor, Head of the Department of Professional Education and Technologies of Agricultural Production, Oleksandr Dovzhenko Hlukhiv National Pedagogical University, Ukraine ${ }^{2} \mathrm{PhD}$ in Pedagogy, Senior Lecturer of the Department of the Vocational Education and Computer Technologies, Oleksandr Dovzhenko Hlukhiv National Pedagogical University, Ukraine ${ }^{3}$ Assistent of the Department of the Vocational Education and Computer Technologies, Oleksandr Dovzhenko Hlukhiv National Pedagogical University, Ukraine
} 
organized within the School of Pedagogy. To develop pedagogical skills different forms of organizing educational process and self-education are to be used, which can help in forming a teacher of a new formation. On gaining some certain experience, the authors come to the following conclusions:

1. In the process of problem solving learning realized more effective assimilation of knowledge and activity methods, through the analysis of problem implying situations, problems formulation and the means for their solution by making assumptions, substantiation and hypothesis.

2. The use of trainings is conditioned by their ability to improve one's interpersonal interaction skills, professional abilities development, stereotypes change that make it hard for the person to cope with non-standard situations in one's professional activity, opportunities for self-realization in the future profession and communication. Participation in training courses helps students to become aware of their own shortcomings on the way to masterying their verbal and non-verbal skills, to identify and evaluate potential prospects, to put their knowledge into practice.

3. The use of didactic games promotes the student transformation directed to not be regarded as the object of study but the subject of professionally oriented work, which causes one's purposeful activity and creative participation in the independent formation of professional competence.

4. The development of critical thinking helps the student to expand one's mental competencies in effectively solving social, scientific and practical problems.

5. In the project activity students develop their abilities to identify and realize a common goal of work and find the ways to achieve it; ability to agree on the division of functions and roles in the joint activity; to exercise mutual constructive control in joint activities, to resolve conflicts taking into account the interests of the parties, to cooperate.

6. The development of student's digital competence involves the improvement of knowledge about sources, types, structure of information, formation of skills to use methods of working with information, value attitude to information and evaluation of their own activities.

7. An important condition for the formation of communicative skills of future educators is real professional conditions of communication modeling in order to involve each student into the process of practical communication activities. 


\section{Introduction}

The socio-economic changes that take place in the beginning of the 21 st century in our country reveal the demands conserning the educational process organization in higher educational institutions, aimed at forming students' general and professional competences, which are to be adequate to the requirements of the modern labor market. Reforming higher education in Ukraine, transition to a new personality-oriented approach in education and training is impossible without creating the necessary conditions to ensure the sustainable development of the teacher. It is the existence of an appropriate level of professional and pedagogical competence as a taxonomic hierarchical structural unity of lower-level competences of teachers, which is in line with the demands of a globalized informative society, and is a key to the development of society in general and the higher education system in particular. In the process of searching for a new educational paradigm, widespread acquisition of various types and forms of professional education, which is a leading condition for the individual comprehensive development, the enrichment of his creative potential, a means of realizing abilities, as well as the increase of professional competence, the improvement of previously acquired knowledge, skills and abilities. Today, there is a contradiction between the need to develop the pedagogical skills of the future teacher of vocational training and the lack of appropriate scientific and methodological support for realizing this process.

Therefore, the implementation of a set of measures aimed at solving problems in developing future vocational training teachers' pedagogical skills is being of particular importance at the national, regional and sectoral levels.

The modern educational paradigm implies a comprehensive update of the future spesialists professional training. This process is updated due to the dramatic changes in the education system. In this context, the development, in fact, of the teacher of vocational training personality is of particular importance, not only in arming his professionally necessary scientific and theoretical knowledge, but also in regard to his humanistic essence. This puts the need for a transition from an authoritarian-disciplinary model of learning to a personality-oriented one, the defining feature of which is understanding, interaction, and creative collaboration.

Profession-oriented training of a modern teacher of vocational training is oriented on the formation of professional values, requires clearly defined 
educational goals and motives, organization and design of psychological and pedagogical conditions of the educational process, aimed at a specialist with a modern type of professional thinking, capable of developing a professional professional market. These necessitates imply the formation of appropriate knowledge and skills, analysis of socio-economic changes in the labor market, adequate perception of the modern professional activity goals and motives.

In such circumstances, it is important to be able to organize the educational process as an interaction aimed at personal development, to carry out a culturally creative and life-giving mission. Known styles and teaching methods nowadays appear to be somewhat outdated and do not fully contribute to students' competencies. This problem can be solved through the formation and development of skills to select and apply such styles and teaching methods that will promote the acquisition of knowledge and the development of the overall ability for creative thinking and active behavior.

Therefore, when organizing an educational process, it is important to remember that learning occurs when a person changes their attitude or behavior for the better, according to their own outlook. These requirements can be fulfilled in the case of reforming the general structure of training, updating the curricula, adapting them to the current conditions and using modern teaching methods.

The practical implementation of this task depends to a large extent on the teaching staff, their skills and professionalism, so teaching methods should maximally contribute to the achievement of the set goal and the fulfillment of the corresponding tasks.

It is important for the modern teacher of vocational training to realize the tasks, which include: developing a new type of critical and creative thinking of students, including the ability to compare and analyze facts, to reasonably defend their own point of view; the formation of sound theoretical knowledge and the ability to put them into practice.

Therefore, teachers need to master techniques that stimulate constructive-critical thinking, develop creative ability. Achieving these goals is possible only if you implement an innovative, creative approach to the learning process. The application of innovative approaches to teaching based on modern teaching methods and technologies implies a fundamental change in the methodological stereotypes that have formed among teachers $[1 ; 2 ; 3 ; 4]$. 


\section{The essence of the «pedagogical mastery» concept}

In the modern conditions of innovative development of society the issue of professional development of specialists in all spheres, including education, is actualized. Technological development requires the training of future specialists for various sectors of the economy in accordance with the needs of the labor market and society.

In this regard, it is necessary to introduce effective technologies and teaching methods in the education system, to develop pedagogical skill of teachers, which is considered by scientists as an ideal of pedagogical activity and as a standard containing an assessment of the effectiveness of pedagogical work. Pedagogical skill encourages teachers to improve themselves, because they are mostly perceived as the most important professional quality of the teacher's personality.

Our research on the problem of pedagogical excellence convinces the diversity of views on this phenomenon. The results of the analysis are summarized in table 1.

Table 1

\section{The essence of «pedagogical mastery» concept in the researches of scientists}

\begin{tabular}{|l|l|}
\hline \multicolumn{1}{|c|}{ Author } & \multicolumn{1}{c|}{ Definition } \\
\hline $\begin{array}{l}\text { I. Ziazun } \\
\text { [5, p. 30] }\end{array}$ & $\begin{array}{l}\text { Pedagogical mastery is a complex of personality traits that } \\
\text { provides a high level of self-organization of professional activity } \\
\text { on a reflective basis. }\end{array}$ \\
\hline $\begin{array}{l}\text { V. Slastionin } \\
\text { [6, p. 369] }\end{array}$ & $\begin{array}{l}\text { Pedagogical mastery acts as a combination of personal and } \\
\text { business qualities and professional competence of the teacher, } \\
\text { as a complex of personality traits that provide a high level of } \\
\text { self-organization of professional and pedagogical activity. At } \\
\text { the same time, a high level of development of a number of } \\
\text { professional skills gives skill, and theoretical knowledge and } \\
\text { skills based on it is the main, objective content of pedagogical } \\
\text { skill, unified and common for all teachers. }\end{array}$ \\
\hline $\begin{array}{l}\text { O. Shcherbakov } \\
\text { [7] }\end{array}$ & $\begin{array}{l}\text { Pedagogical mastery is a synthesis of scientific knowledge, skills, } \\
\text { methodical art and personal qualities of the teacher; it is an expression } \\
\text { of «the totality of the mental properties of his personality». }\end{array}$ \\
\hline $\begin{array}{l}\text { N. Kuzmina } \\
\text { [8, p. 30] }\end{array}$ & $\begin{array}{l}\text { Pedagogical mastery - «the highest level of pedagogical activity, } \\
\text { which is manifested in the fact that in the allotted time the teacher } \\
\text { achieves optimal results,» or «synthesis of scientific knowledge, } \\
\text { skills and methodical skills and personal qualities of the teacher.» }\end{array}$ \\
\hline
\end{tabular}


End of Table 1

\begin{tabular}{|c|c|}
\hline Author & Definition \\
\hline E. Tunic [9] & $\begin{array}{l}\text { Pedagogical mastery - «is the highest level of pedagogical } \\
\text { activity, the highest creative activity of the teacher. It is a } \\
\text { synthesis of scientific knowledge, skills and methodical art and } \\
\text { personal qualities of the teacher, a complex of properties of his } \\
\text { personality, which provides a high level of self-organization of } \\
\text { pedagogical activity. }\end{array}$ \\
\hline $\begin{array}{l}\text { A. Markova } \\
{[10, \text { p. } 51]}\end{array}$ & $\begin{array}{l}\text { Pedagogical mastery is a good mastery of the basics of the } \\
\text { profession, the successful application of techniques known in } \\
\text { science and practice. Mastery means perfect knowledge of the } \\
\text { teacher of his subject, achievement of consistently high results } \\
\text { in learning, mainly the knowledge of students. The teacher's } \\
\text { skill is not directly related to his work experience. In this case, } \\
\text { every teacher, if desired and perseverance, can become a master } \\
\text { of their own business. }\end{array}$ \\
\hline $\begin{array}{l}\text { V. Skakun } \\
{[11, \text { p. } 168]}\end{array}$ & $\begin{array}{l}\text { The professional mastery of industrial training is a complex } \\
\text { concept that reflects at the same time a synthesis of its various } \\
\text { qualities, scientific, technical, pedagogical knowledge and } \\
\text { skills that enable it to achieve the best results in the education, } \\
\text { upbringing and development of its students through a system of } \\
\text { pedagogical means. }\end{array}$ \\
\hline $\begin{array}{l}\text { M. Dyachenko and } \\
\text { L. Kandibovich } \\
{[12, \text { p. } 169170]}\end{array}$ & $\begin{array}{l}\text { Pedagogical mastery is a high level of professional activity } \\
\text { of the teacher. From the outside, it manifests itself in the } \\
\text { successful creative solution of a variety of pedagogical tasks, } \\
\text { in the effective achievement of the methods and goals of } \\
\text { educational work. From the inside, skill is a functioning system } \\
\text { of knowledge, skills, psychic processes, personality traits that } \\
\text { ensures the fulfillment of pedagogical tasks. }\end{array}$ \\
\hline $\begin{array}{l}\text { V. Madzigon } \\
{[13, \text { p. } 300]}\end{array}$ & $\begin{array}{l}\text { Mastery is a high art in any field, skill in performing a certain } \\
\text { activity. Skill implies the availability of professional knowledge, } \\
\text { skills ... Skill is also a trait that distinguishes one employee from } \\
\text { another, because he creates something unique, non-standard. }\end{array}$ \\
\hline $\begin{array}{l}\text { G. Hoziainov } \\
{[14, \text { p. } 81]}\end{array}$ & $\begin{array}{l}\text { High art of performing educational activities on the basis of } \\
\text { knowledge, personal qualities and pedagogical experience } \\
\text { manifested in a complex solution tasks of education, upbringing, } \\
\text { development of the student. }\end{array}$ \\
\hline $\begin{array}{l}\text { V. Sukhomlinsky } \\
{[15, \text { p. } 595]}\end{array}$ & $\begin{array}{l}\text { The art of influencing childrenthat awakens their self- } \\
\text { knowledge. }\end{array}$ \\
\hline $\begin{array}{l}\text { A. Makarenko } \\
{[16, \text { p. } 368-369]}\end{array}$ & $\begin{array}{l}\text { Knowledge of the pedagogical process, the ability to construct it, } \\
\text { to set in motion. }\end{array}$ \\
\hline $\begin{array}{l}\text { S. Sysojeva } \\
{[17, \text { p. 30] }}\end{array}$ & $\begin{array}{l}\text { Synthesis of scientific knowledge, skills and methodical art and } \\
\text { personal qualities of the teacher. }\end{array}$ \\
\hline
\end{tabular}


Note that the characteristics of pedagogical skills, highlighted in the above definitions, are reflected in the reference literature:

- is a high-quality up-and-coming art of education that is accessible to every teacher who works by vocation and loves children. The teacher is a specialist of high culture, who knows his subject deeply, is well acquainted with the relevant fields of science or art, is practically versed in the issues of general and, especially, child psychology, has a thorough knowledge of teaching and upbringing methods" [18, p. 739].

- is a characteristic of high-level pedagogical activity, the main feature of which is the impeccable ability to teach their students, to form in them positive personality and character traits" [19, p. 235].

- is a high level of mastery of pedagogical activity; a set of special knowledge, skills and competences, professionally important personality traits that enable the teacher to effectively manage the students' educational and cognitive activity and to pursue purposeful pedagogical influence and interaction [20, p. 78].

- is a characteristic of a high level of pedagogical activity, which is based on the high professional level of the teacher, his general culture and pedagogical experience. Necessary conditions for pedagogical skills are the humanistic position of the teacher and professionally significant personal traits and qualities [21, p. 251].

The analysis of the above mentioned approaches to understanding the essence of pedagogical skill has led to the conclusion that they have considered this phenomenon in at least three planes: first, as a characteristic of the results of pedagogical activity; second, as a characteristic of the process of pedagogical activity; third, as a set of internal characteristics of the teacher's personality that ensure the effectiveness of his professional activity.

Mastery is determined by the development of appropriate substructures and personality traits associated with such active manifestations as operational-technical, motivational-needy, cognitive, moral-willed. It is formed on the basis of practical experience and has its meaningful expression and functional purpose. However, in every field of science and production skill has its specific characteristics, although the purpose and the end result of differences in the interpretation of this concept is not: skill is always associated with improving the efficiency of activity. Teacher skills are directly related to creativity, where the intuition, inspiration, and talent of the teacher 
play a big role. The most important condition for the growth of skill is creative, based on continuous improvement of pedagogical activity. Crucial in the development of skill is the closest environment in which the teacher gets: the microclimate of the team, its ideas, traditions [22].

We agree with the opinion of A. Makarenko, who believed that anyone can become a master if they can help him and work independently for improvement [16]. The teacher was convinced that the skill develops in the activity, but it is not limited to, but limited only by the high level of development of social skills. Teachers need to be taught how to teach a doctor or musician [16, p. 236]. A. Makarenko believed that it is impossible to bring up only talent in the youth, it is necessary to speak about skill a real knowledge of the educational process and brought up skills. Specificity of pedagogical skill reflects the position of the teacher, his ability to show creative initiative.

\section{Creating an environment for the development of pedagogical mastery of future Vocational Training Teachers}

The leading purpose of vocational education is to ensure the competitiveness of graduates and their mobility in the labor market, and the priority of vocational training is the creative development of personality.

Changes in the economic and educational spheres require continuous updating of the content of training, improvement of its forms and methods. The modernization of the educational sector is aimed at improving the educational process, creating special conditions for the professional training of teachers, in particular in the system of advanced training. Improving the quality of pedagogical activity requires awareness and understanding of the causes, factors that affect the effectiveness, success, quality of education, and the identification of certain conditions under which it can be implemented.

The Department of Vocational Education and Technology of Agricultural Production of Olexander Dovzhenko Hlukhiv National Pedagogical University after created an environment for the development of pedagogical skills, as well as experienced teachers and future ones (Figure 1).

The Scientific Laboratory «Innovative Teaching Technologies» (headed by Prof. Kovalchuk V. I.) is established and actively working at the department. The laboratory is a structural unit of the University in the field of research work on creation of innovative projects and introduction of inno- 
vative technologies in the educational process. The research and scientific-practical work of the laboratory is performed by: the teaching staff of the departments and teaching staff of the University, graduate students, doctoral students and applicants who work on dissertations in the field of problems relevant to the scientific profile of the department; students in the pricess of coursework, diploma work and projects, production practices, and other research work; other personnel who have an interest in and ability to conduct research on problems being developed by the laboratory.

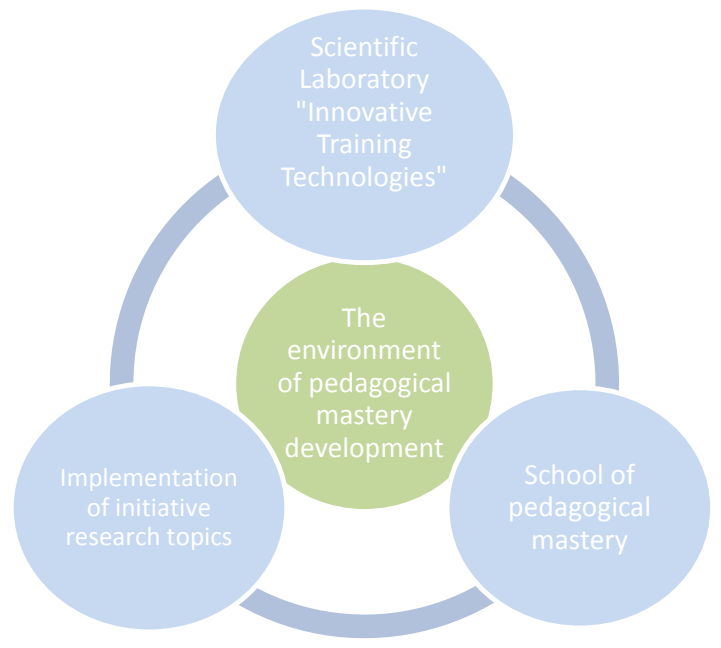

Figure 1. Environment for the development of pedagogical skills

The goals of the laboratory are: meeting the needs of the individual in scientific, intellectual, cultural development; meeting the needs of society and the state for qualified specialists with higher education and scientific and pedagogical staff of higher qualification; development and introduction of innovative educational technologies in the educational process, improvement and modernization of the educational process, improvement of the quality of education.

Among the tasks of the laboratory are: studying and generalizing domestic and foreign experience in the field of innovative educational technologies; development of experimental educational programs (including 
copyrights), scientific hypotheses and concepts of content development of educational subjects, new pedagogical theories and practices, methods and techniques, educational techniques and technologies, as well as programs of research monitoring works; development of concepts (conceptual models) and programs of research experiment and providing practical assistance in the development and carrying out of individual experimental and research works, modeling of lessons, educational and cognitive situations, etc.; conducting diagnostic studies of the state of innovative educational processes and their impact on the formation of the personality of the student and the teacher; formation and implementation of databases and software products.

The tasks of the laboratory are realized during the implementation of the initiative theme of the research work «Development of pedagogical skills of the teacher of vocational training in the conditions of educational transformations». The objectives of the study are:

1. To substantiate theoretical and methodological approaches to the problem of development of pedagogical skill of teacher of professional training of institutions of professional (vocational-technical) education.

2. To identify tendencies and regularities of development of pedagogical skill of teacher of professional training of institutions of professional (vocational-technical) education.

3. To substantiate the system of development of pedagogical skills of the teacher of vocational training.

4. To clarify the essence of the concepts of «pedagogical skill», «development of pedagogical skill of the teacher of vocational training», «system of development of pedagogical skill of the teacher of vocational training» and their role in the content of vocational education.

5. To develop author's programs, educational, educational-methodical manuals for development of pedagogical skill of teacher of vocational training.

6 . To try modern methods of development of pedagogical skill of teacher of professional training.

For the purpose of formation and development of practical skills the «School of pedagogical skill» was created whose tasks are:

- forming the readiness of pedagogical staff to modernize the content of the educational process;

- search for effective forms, methods of organization of educational process in institutions of vocational (vocational-technical) and higher education; 
- methodological support of innovative activity;

- development of the teacher's original pedagogical style;

- development, modeling, approbation, correction and realization of educational technologies, presentation and dissemination of the results of teachers' activity;

- building an individual trajectory of teacher development;

- deepening of practical and creative cooperation between teacher and student;

- creation of conditions for teacher's self-education and self-development [21].

\section{Technologies of pedagogical mastery development}

Today in pedagogical practice a considerable arsenal of methods of development of pedagogical skill is developed. We have identified the technologies and teaching methods that we believe are most effective in developing the pedagogical skills of VET teachers.

In the practice of work of the School of pedagogical skill the most commonly used training technologies of training. The use of trainings is conditioned by their ability to develop skills of interpersonal interaction, development of professional abilities, change of stereotypes that prevent the person to cope with non-standard situations of professional activity, opportunities of self-realization in the future profession and communication. The training is aimed at helping students to become aware of their own deficiencies in the development of verbal and non-verbal skills, to identify and evaluate potential opportunities, to put their knowledge into practice.

Training includes various methods of work: analytical exercises, psychotraining, expert work, assessment of self-identity, stimulates students' desire for self-improvement.

The value of trainings for the higher education system is that they allow to intensify the process of vocational training, saving time and space, with making it more effective by fully complying with the principles of personally oriented learning. The training program «How to become a skilled teacher» includes the most problematic issues in the teacher's activity and updated requirements for the organization of the educational process:

- Creating a supportive educational environment;

- Person-centered approach to learning. Learning styles; 
- Forming learning outcomes and objectives;

- An empirical model of learning;

- Active teaching methods;

- Feedback;

- Development of critical thinking;

- Development of communication skills;

- Use of digital technologies in the educational process.

One of the most promising ways of developing the creative abilities of the individual needed by the modern specialist is the problem of learning. Such training involves problematic teaching, that is, creating a system of sequential problem situations and managing the process of solving them, as well as problematic learning - a special form of students' creative learning activities in the acquisition of knowledge and methods of activity with the presence of problem situations analysis, formulation of problems and their solution by nomination. assumptions, substantiation and hypothesis.

Modern innovation trends in education open to teachers a wide choice of learning philosophy and ways to solve practical problems. There is a transition from learning the facts to mastering the meaning of events, the development of worldview, the acquisition of skills in the life of accumulated knowledge, which is possible in the conditions of using such tools of interactive technologies, such as games.

The game environment encourages the student to show «super-situational activity» when he goes beyond what objectively requires a role for him, and on the basis of initiative-creative approach produces new ideas, ways of solving professional problems, etc. The use of didactic games promotes the transformation of the student from the object of study into a subject of professionally directed work, which causes his purposeful activity and creative participation in the independent formation of professional competence.

Play is a special activity that determines the physical condition and social preferences of a person at the moment, which corresponds to the life of the group or groups of which the student is a member. It is in the game that we can observe the following processes:

- competitions, conflicts, cooperation, accommodation («adaptation to others»));

- assimilation ("likening to others");

- socialization ("the process of social formation of a person"). 
Among these processes, the most significant, in our opinion, is collaboration (both in place of play and in influence on the student). Integration of the group is accompanied by conscious and unconscious learning of group ideals and ideas, acquiring which students become accustomed to each other, become an organic part of the group and at the same time socialized, since the types of games and ideals are determined by society (formation of personality, useful society and group unity).

It is in the game that self-expression of the personality takes place. Therefore, the meaning of the game should be seen as the ability of the student to express themselves in it, to gain public approval, enjoy their opportunities, get rid of internal tension.

Interest in the game as a particular activity is absolutely justified, because it provides high efficiency in any activity and at the same time promotes the harmonious development of the individual. Game behavior and game interaction allow to form mechanisms of cooperation with the partner and competition with the opponent, it is used for removal of psychological stresses, for rest and discharge, for training and education [24, p. 4-6].

Scientific works also point to the emergence of pleasant human relations between students and educators during the game, which occur against the background of cathartic experiences, sensual co-creation and intellectual cooperation [25, p. 93].

Thus, according to A. Markova, in the process of business games, the language of communication is activated, which teaches a person to be more expressive, contributes to a better understanding of it by other people. In addition, because the participants in a business game have several goals: the game (the purpose of the role), the work (as a participant in a joint activity) and professional (mastery in the business game of professional qualities and skills) - they develop the ability not to identify these different interests , which in itself develops the participant [26, p. 162].

$\mathrm{V}$. Barkasi believes that in the business game there is an enrichment of each participant with new ideas about himself, his professional competence on the basis of comparison of assessments, freedom of role maneuver [27].

Scientists also note that during a business game the ability to make decisions and organize its implementation is formed, with participants having the opportunity to see the results of their actions, to evaluate them. The experience gained during the game does not detach from actual practice. The author 
also points to the appearance of pleasant human relations between the participants of the game, which occur against the background of cathartic experiences, sensual co-creation and intellectual cooperation [27, p. 93].

Business games should teach vocational training teachers to manage their well-being in order to increase pedagogical activity.

The development of critical thinking has been identified as one of the main skills of the 21st century. This is a topical topic in all business and scientific forums.

Technology for the development of critical thinking includes goals, objectives, principles of construction, stages and conditions of formation, methods, techniques and methods of teaching thinking, forms of organization of students' activities and ways of evaluating the results of thinking.

The main purpose of developing students' critical thinking is to expand their mental competences to effectively solve social, scientific and practical problems.

The main goals of technology:

1) familiarize yourself with the basic principles of critical thinking;

2) to get acquainted with some methods and means of development of critical thinking in high school educational practice.

Critical thinking is a set of cognitive skills that implies that the person who possesses it:

- is able to express his thoughts (verbally and in writing) clearly, confidently and correctly regarding others;

- is able to work with the growing and constantly changing information flow in different fields of knowledge; distinguish essential information from irrelevant, relevant from irrelevant;

- is able to argue his point of view and take into account the views of others;

- is able to evaluate the origin of knowledge, its authenticity and credibility;

- takes into account the diversity of perspectives on the problem; takes into account the context of any information, problem, situation;

- knows how to ask questions, formulate a hypothesis independently, distinguish real problems from imaginary ones;

- is capable in producing one's own opinion on the basis of understanding of different experiences, thoughts and ideas; 
- reveals hidden assumptions and biases, stereotypes and prejudices;

- is doing self-study on one's own;

- finds alternative ways of solving problem situations;

- -is able to explain what has been learned and apply it in everyday life;

- -is able to evaluate his own thought process using such intellectual standards as clarity, accuracy, relevance, logic, significance [34].

Increasingly relevant in the educational process is the use of techniques and methods that help to form the ability to independently acquire new knowledge, gather the necessary information, put forward hypotheses, draw conclusions. In recent years, this problem has been solved in higher education institutions, in particular through the organization of project activities. The project method is the basis of project training, the meaning of which is to create the conditions for students to learn the material in the course of project implementation.

Design technology is the solution by a student or a group of students of any problem, which involves, on the one hand, the use of different methods, teaching aids, and on the other - the integration of knowledge, skills in different fields of science, technology, creativity.

The method of projects allows to turn classes into a discussion, research club, in which interesting, practically significant problems are solved. It can be applied both in class and out of class. It provides for the development of the cognitive activity of the student, motivated by the problematic confrontation of the known and the unknown, with the aim of intensifying the process of cognition and comprehension of the new, as well as the acquisition of new lexical units, allowing to make learning feasible for all students through their participation in various projects [28].

The main purpose of project activity development is to develop the ability of each student to identify and realize a common goal of work and find ways to achieve it; ability to agree on the division of functions and roles in the joint activity; to exercise mutual constructive control in joint activities, to resolve conflicts taking into account the interests of the parties, to cooperate. Also, the method of educational projects acts as a possible means of solving urgent problems: students are often unable to turn information into knowledge, to pursue purposeful search for information; large amount of information does not lead to systematic knowledge; lack of students' interest, motive for personal growth, self-acquisition of new knowledge; 
the leading type of student activity is reproductive, which reproduces knowledge that is detached from life.

Project technology is one of the innovative technologies of education and training that combines theoretical knowledge and their practical application to solve specific life or professional problems.

Design technology provides a successful solution to the problem, which involves, on the one hand, the use of a variety of different methods and learning tools, and on the other - the need to integrate knowledge and skills from different fields of science, technology and creativity.

The method of projects allows to turn classes into a discussion, research club, in which interesting, practically significant problems are solved. It can be applied both in class and out of class. It provides for the development of the cognitive activity of the student, motivated by the problematic confrontation of the known and the unknown, with the aim of intensifying the process of cognition and comprehension of the new, as well as the acquisition of new lexical units, allowing to make learning feasible for all students through their participation in various projects [28].

The main purpose of project activity development is to develop the ability of each student to identify and realize a common goal of work and find ways to achieve it; ability to agree on the division of functions and roles in the joint activity; to exercise mutual constructive control in joint activities, to resolve conflicts taking into account the interests of the parties, to cooperate. Also, the method of educational projects acts as a possible means of solving urgent problems: students are often unable to turn information into knowledge, to pursue purposeful search for information; large amount of information does not lead to systematic knowledge; lack of students' interest, motive for personal growth, self-acquisition of new knowledge; the leading type of student activity is reproductive, which reproduces knowledge that is detached from life.

Project technology is one of the innovative technologies of education and training that combines theoretical knowledge and their practical application to solve specific life or professional problems.

Design technology provides a successful solution to the problem, which involves, on the one hand, the use of a variety of different methods and learning tools, and on the other - the need to integrate knowledge and skills from different fields of science, technology and creativity. 
The project method is considered to be one of the promising types of learning because it creates the conditions for students' creative self-realization, increases the motivation for acquiring knowledge, promotes the development of their intellectual abilities. Students gain experience in solving real-world problems with respect to future independent professional lives that they project in teaching. The need to use this method is due to the fact that today's higher education is a contemporary process of the emergence of a new world open educational space.

In today's digital society, employers' demands for higher education graduates have changed. One of the most important requirements is the ability of the future specialist in digital technology. In the intellectual labor market, professionals with a high level of digital culture and competence are in demand. The modern specialist should be able to receive, process and use information through computers, telecommunications and other means. The task is to form a person who is ready to update knowledge throughout his life's journey. The ability to choose the necessary information, to systematize it, to absorb it at a high level, to navigate in an ever-increasing information flow is an important quality of a graduate of a higher education institution.

The development of a student's digital competence involves mastering knowledge about sources, types, information structure, forming skills to use methods of working with information, value attitude to information and evaluation of their own activities. The degree of development of digital competence can be assessed by the number and quality of information processes in which the individual participates.

In order to effectively develop digital competence, the following pedagogical conditions are needed:

- updating of information component of educational and cognitive activity at all stages of training;

- inclusion of the student in a specially organized, developing, complicated educational and cognitive activity related to the acquisition, storage, processing and transfer of information;

- ensuring the subjective position of the student in the information space of educational and cognitive activity.

The change in the level of digital competence can be caused by the following factors:

- acceptance at the personal level of value of information activity; 
- formation of skills to be competent in the information environment, to apply the scientific organization of work when working with sources of information;

- novelty of the content of education, etc.

The problem of development of digital competence of the student is relevant, because the purpose of modern education is not only the assimilation of knowledge and development of skills, but also the formation of certain personality traits necessary for effective work in the information space, including his worldview, ethical and value orientations, education of responsibility for creation, use and transfer of information [29].

In order to develop information skills in students, we primarily included elements of multimedia support of the study material (presentations on a specific topic of the course; computer diagnostic methods, tests, etc.), as interactivity and generalization of various types of information, in the content of the classroom the ability to take into account the individual characteristics of students and increase their motivation, make multimedia content particularly effective and productive technologies in the educational process. Distance courses are being developed based on the use of the distance learning system.

The problem of developing communication skills of students is of particular importance, because it is the level of development of such skills that determines the professional competence of the future specialist. Higher education requires not only explaining to the student the facts, phenomena, processes, understanding and interpretation of the information received, but above all - the ability to put into practice the acquired knowledge, that is, the orientation is made not on the learning process, but on the result of the educational process - the readiness of the graduate for further vocational communication activities [30].

The ability to communicate allows professionals to interact with other people, adequately interpret the information received and properly convey it. Students need to learn how to listen to an interlocutor, express and argue their point of view, come to a compromise solution. Communication skills are important both for the social realization of the individual and for the psychological satisfaction.

We have observed that students (especially the first two years of study) have difficulty communicating with classmates and teachers, who are unable to listen and critically evaluate someone else's opinion, unable to build their own language when expressing their point of view. To this end, we conduct communication trainings. 
An important condition for the formation of communicative skills of future educators is the simulation of real professional communication conditions in order to involve each student in practical communication activities. The modeling of professional communication conditions means the real reproduction of communication situations, in which students will learn to communicate effectively and master communication skills and skills, using their own experience [31, p. 88].

Modeling of real professional situations will help students to understand and feel in their own experience responsibility for their words, actions, will teach to interact with colleagues, understand them, correctly select language tools for formulation and expression of thoughts [31, p. 88].

Clarifying the concept of communicative training, we can say that it is a form of psychological influence based on active methods of group work, specially organized communication, during which the issues of personality development, the formation of communication skills are solved.

From the point of view of I. V. Hromova, communication skills training is a social and psychological training, the object of which is the communication skills of the individual [32].

The purpose of such training is to overcome communication barriers, which often interfere with the realization of professional abilities, elimination of complexes of personality that arise in the process of communication, learning the difficult art of supporting conversation, the ability to strike up acquaintance, as well as the ability not only to hear, but also to communicate . Unlike business communication training, communicative training involves an emphasis on personal rather than professional communication.

Special conditions are created for the effective organization of communicative training through games and exercises, the laws and peculiarities of relationships, communication and behavior in the world of people are opened, and the qualities and skills important for this are developed [33].

We will build the content of the training in such a way that each participant has the opportunity to develop in three directions:

- significant personal qualities and experience;

- different techniques and methods of practical work;

- technology of organization and evaluation of practical results.

The isolated list, in our opinion, is basic and does not exhaust the full list of methods and technologies used in the preparation of the future teacher of 
vocational training. It is extremely important to use a predictive approach to preparation, as technologies change very rapidly in the digital age. Teachers need to remember that they are teaching future professionals who will use technologies that are not yet known today. Those we teach today in the first year will work from 2024 to 2064, and the children they teach will start working from 2040. Therefore, the highest level of pedagogical skills will be the formation and development of those skills that will help today's students to realize in the future.

\section{Conclusion}

The education of vocational training teachers should ensure the development of their professional competence, which is manifested in the teacher's attitude to the world and himself, the way of self-affirmation, the attainment of a higher degree of professional activity and skill. This allows to overcome a certain absolutization of the individualistic or collectivist principle of organizing the system of teacher training of a vocational school on the basis of a combination of a common goal with the immediate interests of the individual, the need for freedom in the choice of content and forms of learning.

Achieving a higher level of mastery of the teacher significantly changes the pedagogical reality, which contributes to the formation of the creative orientation of the individual and guarantees the full disclosure of the creative abilities of each student. Thanks to the skill of the teacher creates an atmosphere of efficiency and understanding, based on the relationship of participation, active mutual assistance. So, we can sum up that the teacher-master is a highly developed personality, a specialist in high culture, a master of his or her business, who has perfect knowledge of psychological knowledge, knowledge in various fields of science and art, and knowledge of the subject he teaches, methods of teaching and upbringing.

To develop pedagogical skills, it is necessary to use different forms of educational process and self-education, which will help to form a teacher of a new formation.

The development of pedagogical skills is facilitated by innovative technologies and teaching methods. We have distinguished: training technologies; game technologies; project learning technologies; technologies of development of critical thinking; digital competence development technologies; communication technologies and others. 


\section{References:}

1. Kovalchuk V.I., Serghejeva L.M. ta in. (2007). Jak staty majsternym pedaghoghom : navchaljno-metodychnyj posibnyk [How to Become a Skilled Teacher: A Toolkit]. Kyiv: Etis pljus, 184 p. (in Ukrainian)

2. Kovalchuk V.I. (2009). Tekhnologhija navchannja doroslykh na osnovi osobystisno orijentovanogho pidkhodu: treningh [Adult learning technology based on a person-centered approach: training]. Kyiv: Shkiljnyj svit, 136 p. (in Ukrainian)

3. Kovalchuk V.I. (2009). Innovacijni pidkhody do orghanizaciji navchaljnogho procesu $v$ PTNZ: speckurs dlja pidvyshhennja kvalifikaciji kerivnykh $i$ pedaghoghichnykh kadriv osvity [Innovative approaches to the organization of educational process in VET: a special course for advanced training of managerial and pedagogical staff of education]. Kyiv: Shkiljnyj svit, 136 p. (in Ukrainian)

4. Kovalchuk V.I. (2017). Metodyka vykladannja u vyshhykh navchaljnykh zakladakh: praktykum [Teaching Methods in Higher Education: Workshop]. Kyiv: Milenimum, 428 p. (in Ukrainian)

5. Pedagogichna majsternist / za red. akademika APN Ukrayiny I.A. Zyazyuna (1997). [Pedagogical skills]. Kyiv: Vyshha shkola. (in Ukrainian)

6. Slastenin V.A. (1994). Antropologicheskiy podhod v pedagogicheskom obrazovanii [Anthropological approach in teacher education]. Narodnoe obrazovanie, no. 9-10, pp. 124-126.

7. Scherbakov A.I. (1967). Psihologicheskie osnovyi formirovaniya lichnosti sovetskogo uchitelya $v$ sisteme vyisshego pedagogicheskogo obrazovaniya [Psychological foundations of the formation of the personality of the Soviet teacher in the system of higher pedagogical education]. Leningrad: Prosveschenie. (in Russian)

8. Kuzmina N.V., Kuharev N.V. (1976). Psihologicheskaya struktura deyatelnosti uchitelya [Psychological structure of the teacher]. Gomel. (in Russian)

9. Tunyk E.Yu. (2008). Opredelenie urovnya pedagogicheskogo masterstva prepodavatelya fizicheskogo vospitaniya $\mathrm{v}$ vuze [Determination of the level of pedagogical skills of a teacher of physical education in high school]. Pedagogika, psyxologiya ta medyko-biologichni problemy fizychnogo vyxovannya $i$ sportu [Pedagogy, psychology and medical and biological problems of physical education and sports]. No. 11, pp. 148-152.

10. Markova A.K. (1993). Psihologiya truda uchitelya. Kniga dlya uchitelya [Psychology of teacher's work. Teacher's book]. Moskva: Prosveschenie. 192 p. (in Russian)

11. Skakun V.A. (2007). Organizatsiya $i$ metodika professionalnogo obucheniya : uchebnoe posobie [Organization and methods of vocational training: study guide]. Moskva: Forum: Infra-M., 336 p. (in Russian)

12. Dyachenko M.I., Kandyibovich L.A. (1978). Psihologiya vyisshey shkolyi [Psychology of higher education]. Minsk: Izd-voBGU, 203 p. (in Russian)

13. Yarmachenka M.D. (2002). Pedagogichnyj slovnyk [Pedagogical Dictionary]. Kyiv: Pedagogichna dumka, 516 p. (in Ukrainian)

14. Pedagogicheskaya entsiklopediya (1965). [Pedagogical encyclopedia]. Moskva: Sovetskaya entsiklopediya, vol. 2, 844 p. (in Russian) 
15. Khozyainov G.I. (1991). Pedagogicheskaya struktura obuchayushchey deyatel'nosti $i$ formirovanie masterstva pedagoga $v$ uchebnom protsesse [Pedagogical structure of teaching activity and formation of teacher's skill in the educational process] (PhD Thesis). Moskva, 39 p. (in Russian)

16. Sukhomlynsjkyj V.O. (1976). Vybrani tvory: v p'jaty tomakh [Selected works: in five volumes]. Kyiv: Radjansjka shkola, vol. 1, 509 p. (in Ukrainian)

17. Makarenko A.S. (1984). Iz opyta raboty [From work experience]. Pedagogicheskie sochineniy: v 8 t. Moskva: Pedagogika, vol. 4, 484 p. (in Russian)

18. Sysojeva S.O. (2007). Teoretychni ta metodychni zasady rozvytku pedaghoghichnoji osvity : pedaghoghichna majsternistj, tvorchistj, tekhnologhiji [Theoretical and methodological foundations of pedagogical education development: pedagogical skills, creativity, technologies]. Konceptualjni zasady profesijnoji pidghotovky pedaghogha do tvorchoji dijaljnosti : zb. nauk. pracj. Kharkiv : NTU «KhPI», pp. 150-155. (in Ukrainian)

19. Goncharenko S.U. (2000). Profesijna osvita. Slovnyk : navch. Posib [Professional education. Dictionary: Teacher manual] / red. N.G. Nychkalo. Kyiv: Vyshha shkola, 380 p. (in Ukrainian)

20. Zadorozhna L.V. (2000). Ideyi pedagogichnoyi majsternosti v diyalnosti Gluxivskogo vchytelskogo instytutu (1874-1917 rr.) [The ideas of pedagogical skills in the activity of the Glukhiv Teachers' Institute (1874-1917)] (PhD Thesis), Lugansk. (in Ukrainian)

21. Goncharenko S.U. (1997). Ukrayinskyj pedagogichnyj slovnyk [Ukrainian Pedagogical Dictionary]. Kyiv: Lybid, 376 p. (in Ukrainian)

22. Romanova K.E. (2010). Metodicheskaya sistema formirovaniya i razvitiya pedagogicheskogo masterstva budushchikh uchiteley tekhnologii [Methodological system for the formation and development of pedagogical skills of future technology teachers]( $\mathrm{PhD}$ Thesis), Shuya. (in Russian)

23. Kovalchuk V. (2019). Profesijnyj rozvytok pedaghoghichnykh pracivnykiv. Dosvid naukovoji laboratoriji universytety [Professional development of teaching staff. Universities Science Lab Experience]. Proftekhosvita, no. 8(128), pp. 5-9. (in Ukrainian)

24. Kovalchuk V.I. (2017). Metodychni rekomendatsii shchodo zastosuvannia ihrovykh tekhnolohii $v$ protsesi vykladannia dystsyplin sotsialno-humanitarnoho tsyklu [Methodical recommendations on the application of gaming technologies in the teaching of social and humanitarian disciplines]. Kyiv: Vydavnycho-redaktsiinyi viddil NUBiP Ukrainy, 56 p. (in Ukrainian)

25. Mazin V.M. (2008). Formuvannya kultury profesijnoyi samorealizaciyi majbutnix uchyteliv fizychnogo vyxovannya [Formation of a culture of professional self-realization of future teachers of physical education] ( $\mathrm{PhD}$ Thesis), Zaporizhzhya. (in Ukrainian)

26. Markova A.K. (1993). Psihologiya truda uchitelya. Kniga dlya uchitelya [Psychology of teacher's work. Teacher's book]. Moskva: Prosveschenie, 192 p. (in Russian)

27. Barkasi V.V. (2004). Formuvannya profesijnoyi kompetentnosti v majbutnix uchyteliv inozemnyx mov [Formation of professional competence in future teachers of foreign languages] (PhD Thesis), Odesa. (in Ukrainian) 
28. Yakusheva S.D. (2004). Uchebnoe posobie distsiplinyi «Osnovyi pedagogicheskogo masterstva» [The manual discipline «Fundamentals of pedagogical skills»]. Orenburg : RIK GOU OGU, 230 p. (in Russian)

29. Kariev S.K., Mendalieva Sh.O. Razvitie informatsionnoy kompetentnosti $v$ khode uchebno-poznavatel'noy deyatel'nosti [Development of information competence in the course of educational and cognitive activities]. URL: http://www.rusnauka.com/14_NPRT_2010/Pedagogica/66449.doc.htm (in Russian)

30. Drobjazko Ju.I. Spivrobitnyctvo vykladacha i studenta v procesi formuvannja komunikatyvnykh uminj ta navychok [Collaboration of teacher and student in the process of forming communicative skills]. URL: http://confesp.fl.kpi.ua/ru/ node/1058 (in Ukrainian)

31. Romanovsjkyj O.Gh., Butenko T.O. (2009). Pedaghoghichni umovy formuvannja komunikatyvnoji kompetentnosti majbutnikh inzheneriv [Pedagogical conditions of formation of communicative competence of future engineers]. Teorija i praktyka upravlinnja socialjnymy systemamy: filosofija, psykhologhija, pedaghoghika, sociologhija, no. 3, pp. 86-93. (in Ukrainian)

32. Gromova I.V. (2014). Istoriya vozniknoveniya i sovremennye tendentsii razvitiya kommunikativnogo treninga [The history and current trends in the development of communication training]. Molodoy uchenyy, no. 4, pp. 680-683. (in Russian)

33. Babushkina R.L., Kislyakova O.M. (2013). Emotsional'no-kommunikativnyy trening $\mathrm{v}$ strukture zanyatiy po logopedicheskoy ritmike $\mathrm{v}$ sisteme korrektsii obshchego nedorazvitiya rechi [Emotional-communicative training in the structure of lessons on speech therapy rhythm in the system of correction of general speech underdevelopment]. Materialy IKh Mezhdunarodnoy nauchnoy konferentsii «Spetsial'noe obrazovanie». Pod obshchey redaktsiey V.N. Skvortsova. SanktPeterburg, pp. 17-20. (in Russian)

34. Khalpern D. (2000). Psikhologiya kriticheskogo myshleniya [The Psychology of Critical Thinking]. SPb.: Piter, 512 p. (in Russian) 